\title{
Wybrane aspekty kultu Matki Bożej w Prawosławiu
}

\author{
Jarosław Charkiewicz
}

jarek@cerkiew.pl

\begin{abstract}
Jarosław Charkiewicz, Some Aspects of the Veneration of the Mother of God in Orthodoxy, Elpis, 16 2014: 23-31.
\end{abstract}
\begin{abstract}
The Mother of God is the best example of human holiness. She stands at the head of all the saints venerated by the Orthodox Church.

This article discusses several aspects of the cult of the Mother of God: the birth of her cult, titles of the Mother of God used in the Orthodox Church, her nature and the various ways of veneration.

The cult of the Mother of God, which has existed since the beginning of the Church, is rooted in Scripture and Tradition. It is based on her relationship with her Son, the God-Man Jesus Christ. Although the Mother of God is the most perfect human and her holiness exceeds the angelic world, this cult is very different from the glory that is given exclusively to the Triune God. The cult of the Mother of God is not isolated from the glory given to Jesus Christ. It is based not only from her personal virtues, but above all on her unique role in the economy of salvation. The cult of the Mother of God does not decrease the glory given to Christ, Who is the source of all holiness, including His Mother, but increases that glory. Therefore, in the Orthodox Church, the Theotokos is always praised and represented with Jesus Christ and among other saints, as an expression of the community of celebration and prayer. The veneration of the Mother of God is also closely associated with presenting her as the highest possible model of life for all believers.
\end{abstract}

\begin{abstract}
Streszczenie: Matka Boża jest szczytem ludzkiej świętości. Stoi ona na czele wszystkich świętych, którym Kościół prawosławny oddaje cześć.

W artykule omawianych jest kilka aspektów kultu Bogurodzicy: narodziny jej kultu, tytuły używane w prawosławiu wobec Matki Bożej, jej natura oraz różne sfery kultu.

Kult Bogurodzicy, istniejący od początku istnienia Kościoła, zakorzeniony jest w Piśmie Świętym oraz Tradycji, a bazuje na jej relacjach z Synem, Bogoczłowiekiem Jezusem Chrystusem. Chociaż Bogurodzica jest najdoskonalszym człowiekiem i swą świętością przewyższa cały świat anielski, to cześć jej oddawana zdecydowanie różni się od chwały należnej wyłączenie Trójjedynemu Bogu. Kult Bogurodzicy nie służy umniejszaniu chwały oddawanej Chrystusowi, będącego źródłem wszelkiej świętości, w tym Swojej Matki, lecz potęgowaniu tej chwały. Dlatego też w Kościele prawosławnym Matka Boża jest zawsze wychwalana i przedstawiana z Chrystusem i pośród innych świętych, jako wyraz wspólnoty celebrującej i modlitewnej, a oddawanie czci Bogurodzicy związane jest ze stawianiem jej za najwyższy z możliwych wzór do naśladowania dla ludzi wierzących.
\end{abstract}

Keywords: Mother of God, Orthodox Christianity, worship, Theotokos, Virgin, All-Holy, prayer

Słowa kluczowe: Matka Boża, prawosławie, kult, Theotokos, Dziewica, Najświętsza, modlitwa

Matka Boża stoi na czele pocztu świętych, którym Kościół prawosławny oddaje cześć. Jest Ona szczytem ludzkiej świętości, przewyższającej wszelkie stworzenie, kresem przebóstwienia ${ }^{1}$, „niezmiernie dalekim od miary przebóstwienia zwykłych istot"2, a zatem również pozostałych świętych. „Dziewica jest bardziej święta od wszystkich ludzi i aniołów"3 - naucza św. Mikołaj Kabasilas - wyja-

\footnotetext{
Projekt został sfinansowany ze środków Narodowego Centrum Nauki przyznanych na podstawie decyzji numer DEC-2012/07/N/HS1/01570.

To w niej „zrealizowała się świętość [...], zrealizowany został cel stworzenia świata" - pisze ks. Sergiusz Bułgakow, S. Bułgakow, Prawosławie. Zarys nauki Kościoła prawosławnego, przekł. ks. H. Paprocki, Białystok - Warszawa 1992, s. 133-134.

2 W. Saryczew, O kulcie Matki Bożej, przekł. Z. Kozłowska, [w:] Teksty o Matce Bożej. Prawosławie, cz. 2, wybór, wstęp i oprac. ks. H. Paprocki, Niepokalanów 1991, s. 167.

3 M. Kabasilas, Homilia na uroczystość Zaśnięcia Najświętszej Marii Panny, [w:] Teksty o Matce Bożej. Prawosławie, cz. 1, wybór, wstęp i oprac. ks. H. Paprocki, Niepokalanów 1991, s. 273. Św. Justyn Popović tytułuje ją wręcz „Panią Aniołów”, Sobranije tworenij prepodobnogo Iustina (Popovića). Pnewmatologija. Eschatologia, t. 4, Moskwa 2007, s. 300, a o. Paweł Florenski pięknie opisuje stosunek mocy niebiańskich do Bogurodzicy: „Aniołowie pobożnie drżą przed Nią i radośnie uderzają skrzydłami. Archaniołowie pokornie jej służą. Wielooczni cherubini i sześcioskrzydli serafini dziwią się jej chwale", P. Florenski, Ziemska droga Matki Bożej, przekł. ks. H. Paprocki, [w:] Teksty o Matce Bożej. Prawosławie, cz. 1, dz.cyt., s. 325.
}

śniając jednocześnie, że „w miarę wzrostu świętości następuje zbliżenie do Boga”". „Z powodu bliskości do Boga, z powodu mocy przebóstwienia, z powodu przeniknięcia Matki Bożej przez łaskę, ma Ona nieporównanie większą potęgę niż ta, która została obiecana wierzącym w jej Syna (J 14,12), albowiem jej stan duchowy przewyższa wiarę" - naucza jeden ze współczesnych teologów rosyjskich. Bliskość Bogurodzicy i Boga nie powinna budzić wątpliwości. Wynika ona choćby z samego faktu bliskości jej oraz Jezusa Chrystusa, Którego nosiła w swym łonie, powiła i towarzyszyła Mu przez całe ziemskie życie.

Szczególna cześć oddawana Bogurodzicy w prawosławiu wynika $\mathrm{z}$ jej wyjątkowej, kluczowej roli w ekonomii zbawienia, ścisłej i nierozerwalnej łączności ze zbawczym planem Ojca poprzez Jego Syna, który zrodził się z Dziewicy i Ducha Świętego. To ona przyniosła na świat zbawienie, stając się narzędziem Boga we Wcieleniu Jezusa Chrystusa. Podobnie jak świętość innych świętych, świętość Matki Bożej jest wyjątkowa i niepowtarzalna, wymyka się wszel-

\footnotetext{
4 M. Kabasilas, Homilia na uroczystość Zaśnięcia Najświętszej Marii Panny, dz.cyt., s. 273.

5 W. Saryczew, O kulcie Matki Bożej, dz.cyt. s. 168.
} 
kim możliwym typologiom, o czym będzie mowa w dalszej części pracy. Bogurodzica jest ponad wszelkimi systematyzacjami. Ona jedyna spośród wszystkich ludzi okazała całkowite posłuszeństwo, pełną pokorę wobec Boga i została wywyższona ponad wszelkie stworzenie. Dlatego też nie powinno budzić zdziwienia określenie ks. Sergiusza Bułgakowa, który „miłość i kult Matki Bożej” nazywa „duszą prawosławnej pobożności, sercem ogrzewającym i ożywiającym całe ciało”, „,entrum Kościoła”.

Świętość Bożej Rodzicielki jest w prawosławiu czymś tak oczywistym, że paradoksem byłoby nawet mówienie o zaliczeniu jej do grona świętych, o ile w pierwszych wiekach chrześcijaństwa istniałaby stosowna ku temu procedura kanonizacyjna. Świętość ta jest przy tym jednym z głównych tematów homilii i traktatów św. Ojców.

Nauka Kościoła prawosławnego o Matce Bożej bazuje na Piśmie Świętym oraz Tradycji Kościoła. Stanowiąc jej część składową, posiada ona dwie główne cechy. Po pierwsze, nauka ta jest chrystologiczna i chrystocentryczna, a opierając się na chrystologii, nigdy nie bywa rozpatrywana poza ekonomią zbawienia. Łączność prawosławnej mariologii (jeśli w ogólne można mówić o jej istnieniu jako osobnej nauki w Kościele prawosławnym) z chrystologią w sposób bezpośredni znajduje swój wyraz w nazywaniu Jej Bogurodzicą. Prawosławna mariologia jest w rzeczywistości częścią chrystologii, stanowi jej rozwinięcie, przy czym bez mariologii chrystologia nie byłaby pełna ${ }^{8}$. Po drugie, w prawosławnym nauczeniu o Matce Bożej trudno jest oddzielić kwestie dogmatyczne od czci oddawanej Bogurodzicy, co znajduje swoje uzasadnienie w Tradycji. Włodzimierz Łosski wyraził to następującymi słowami: „O Matce Bożej nigdy nie nauczali apostołowie. [...] Tajemnica Matki Bożej otwiera się wewnątrz Kościoła wiernym, którzy przyjęli słowo Boże. [...] To nie tylko przedmiot naszej wiary, ale i fundament naszej nadziei - owoc wiary, dojrzały w Tradycji”".

W Kościele prawosławnym oddawanie czci Bogurodzicy znajduje swój wyraz nie tyle w usystematyzowanej, istotnej refleksji teologicznej nad jej miejscem w ekonomii zbawienia, co przede wszystkim w modlitewnym obcowaniu z nią i pobożności właściwej dla kultu Matki Bożej ${ }^{10}$. Zatem u źródeł prawosławnej mariologii leży przede wszystkim doświadczenie liturgicznego obcowania z Bogurodzicą, a refleksja teologiczna stanowi jedynie jej kontynuację. Głęboko uzasadniona teologiczne prawosławna mariologia

\footnotetext{
S. Bułgakow, Prawosławie, dz.cyt., s. 132.

S. Bułgakow, Mariologia czwartej Ewangelii, przekł. ks. H. Paprocki, [w:] Teksty o Matce Bożej. Prawosławie, cz. 1, dz.cyt., s. 105.

Chrystologia jest nierozerwalnie związana z mariologią, a mariologia z chrystologią. Nie może być bowiem prawidłowego nauczania o Chrystusie bez właściwej nauki o Bogurodzicy. Por. A. Kniazeff, Mariologia biblijna i liturgia bizantyjska, przekł. ks. H. Paprocki, [w:] Teksty o Matce Bożej. Prawosławie, cz. 2, dz.cyt., s. 84.

9 W. Łosski, Najświętsza, przekł. ks. H. Paprocki, [w:] Teksty o Matce Bożej. Prawosławie, cz. 1, dz.cyt., s. 199-200.

${ }_{10}$ Podkreśla to w szczególności ks. Aleksander Schmemann: A. Schmemann, Maryja $w$ liturgii wschodniej, przekł. J. Prokopiuk, [w:] Teksty o Matce Bożej. Prawosławie, cz. 2, dz.cyt., s. 86 in; por. J. Klinger, Zarys prawosławnej mariologii, [w:] Teksty o Matce Bożej. Prawosławie, cz. 1, dz.cyt., s. 130.
}

w dalszym ciągu „mieści się na innym poziomie, bardziej egzystencjalnym, doświadczalnym i powołaniowym, niż inne podmioty teologii”' ${ }^{11}$. Matka Boża w prawosławiu pozostaje centralnym punktem kultu i pobożności Kościoła, jak też duchowości osobistej i wspólnotowej ${ }^{12}$.

\section{Początki kultu}

Nowy Testament nie zawiera bezpośrednich świadectw by Matka Boża cieszyła się jakąś szczególną czcią wśród uczniów Zbawiciela za Jego ziemskiego życia. Nie mówi o tym ani Syn Boży, ani Jego uczniowie. Obecność Matki Jezusa w pismach nowotestamentowych ma charakter epizodyczny i sprowadza się do kilku ewangelicznych relacji1 ${ }^{13}$. O roli Matki Chrystusa w gronie najbliższych $\mathrm{Mu}$ apostołów nie wspominają też Dzieje Apostolskie czy Listy Apostolskie. Zatem praktycznie całe życie Bogurodzicy upłynęło w tajemniczym ukryciu przed ludźmi, w dobrowolnym przysłonięciu przez życie i zbawcze dzieło jej Syna. Jej chwała pozostawiona została jakby przyszłym pokoleniom

Nie oznacza to jednak, że kult Matki Bożej nie był obecny w chrześcijaństwie od samego początku. Przepowiedziała go zresztą sama, wypowiadając w chwili cudownego poczęcia znamienne słowa: „Oto bowiem błogosławić mnie będą odtąd wszystkie pokolenia"14 (Łk 1,48). Odtąd też wychwalanie Bogurodzicy stało się częścią Tradycji Kościoła, a powyższe słowa świadczą o biblijnych podstawach tego kultu, błędnie przez niektórych badaczy utożsamianego z starożytnym pogańskim kultem życiodajnych sił przyrody, macierzyństwa i żeńskiej zasady ${ }^{15}$.

Na początku wychwalanie Matki Bożej koncentrowało się w miejscach związanych z jej życiem, o czym świadczą np. wykopaliska archeologiczne w Nazarecie ${ }^{16}$. O śladach kultu maryjnego jeszcze przed okresem Soborów Powszechnych świadczą też niektóre pisma apokryficzne. Już w II w. Dziewica Maria stała się nieodłączną częścią chrystologicznej nauki Kościoła. Potwierdzają to utwory św. Ireneusza z Lyonu oraz twórczość pisarzy kościelnych II-III w. (św. Ignacy Teodor, św. Justyn Męczennik, Orygenes), w dziełach których poruszany jest temat dziewictwa Bogurodzicy ${ }^{17}$. Nie był to jednak jeszcze czas, w którym Kościół zwracałby się modlitewnie do Matki Bożej, co czynił już w stosunku do męczenników. Do Bogurodzicy mo-

\footnotetext{
1 N. Nissiotis, Maryja $w$ teologii prawosławnej, przekł. B. GórskaKozłowska, [w:] Teksty o Matce Bożej. Prawosławie, cz. 2, dz.cyt., s. 93.

12 Por. N. Nissiotis, Maryja w teologii prawosławnej, dz.cyt., s. 93.

13 Łk 1,26-38; Mt 1,18-25; Mt 2,14; Łk 2,41-51; Mt 12,49-50; Mk 3,31-35; Łk 8,19-21; J 2,1-11; J 19,25-27.

14 Cyt. za Biblią Tysiąclecia.

15 Por. A. Schmemann, Droga prawosławia $w$ historii, przekł. ks. H. Paprocki, Białystok 2001, s. 204-206.

16 Przedziwny Bóg w świętych swoich. O świętości i o świętych z o. Szczepanem T. Kraśkiewiczem OCD rozmawia Kajetan Rajski, Kraków 2011, s. 23-24.

Nauka o dziewiczości Matki Bożej opiera się na świadectwie nowotestamentowym (Mt 1,18-25; Łk 1,26-35), chociaż Nowy Testament nie mówi bezpośrednio o tym, że Maria pozostała Dziewicą po narodzeniu Jezusa.
} 
dlono się dopiero w IV wieku, a być może jeszcze w wieku $\mathrm{III}^{18}$. W ten sposób, w pewnym sensie, kult męczenników zapoczątkował oddawanie czci Matce Bożej, która szybko zaczęła być postrzegana przez Kościół jako najwyższy ludzki (w porównaniu z niedoścignionym Bogoludzkim, Chrystusowym) wzór życia w Chrystusie, z Chrystusem i dla Chrystusa. Dlatego też św. Cyryl Jerozolimski opiewa Bogurodzicę słowami: „Dzięki tobie prorocy prorokowali, dzięki tobie apostołowie głosili zbawienie narodom" ${ }^{\prime 1}$, a św. Grzegorz Palamas, kontynuując i rozwijając tę myśl, wychwala ją, nauczając: „Ona jest mową proroków, podporą apostołów, umocnieniem męczenników, fundamentem nauczycieli”20 . Oba te cytaty wyraźnie wskazują na miejsce Bogurodzicy wśród świętych i jej relacje z nimi.

Pewnym przełomem w rozwoju kultu Matki Bożej było przeniesienie stolicy Cesarstwa Rzymskiego do Konstantynopola (330). Czyniąc to cesarz Konstantym Wielki poświęcił Nowy Rzym Najświętszej Bogurodzicy, co znalazło swoje odbicie w stołecznym budownictwie sakralnym na jej cześć ${ }^{21}$. Kluczowe znaczenie dla ugruntowania się kultu Matki Bożej i jego burzliwego rozwoju miał III Sobór Powszechny, który zajmując się głównie kwestiami chrystologicznymi, ustanowił też dogmat o Bożym Macierzyństwie Bogurodzicy. Od tego czasu zaczęło powstawać coraz więcej świątyń na cześć Matki Bożej, teologowie dedykowali jej liczne homilie, a hymnografowie opiewali w swoich utworach ${ }^{22}$. Najważniejsze jednak było włączenie Bogurodzicy do liturgii Kościoła, przejawiające się w ustanowieniu pierwszych świąt maryjnych i stałej, intensywnej jej obecności w nabożeństwach. Trudno nie przyznać racji ks. Jerzemu Klingerowi ${ }^{23}$, który jako przyczynę rozwoju kultu Bogurodzicy wskazuje poszukiwanie nowego ideału świętości, jakim na początku V wieku stało się życie monastyczne wraz z jego wymogami. Życie Matki Bożej doskonale odpowiadało realizacji tych wymogów. Zatem od $\mathrm{V}$ w. mamy do czynienie $\mathrm{z}$ kultem Bogurodzicy w pełnym tego słowa znaczeniu, kultem „całkowicie zakorzenionym w kontemplowaniu przez Kościół Bogoczłowieczego Oblicza Zbawiciela"24. Na każdym etapie swojego rozwoju cześć oddawana Bogurodzicy organicznie połączona była i nadal pozostaje z chwałą należną jej Synowi - Jezusowi Chrystusowi.

\footnotetext{
18 A. Kniazeff, Obecność Matki Bożej w liturgii, przekł. ks. H. Paprocki, [w:] Teksty o Matce Bożej. Prawosławie, cz. 2, dz.cyt., s. 54.

${ }_{19}$ Św. Cyryl Aleksandryjski, Homilia 4, cyt. za: A. Bober, Światła Ekumeny. Antologia patrystyczna, Kraków 1995, s. 141.

20 Św. Grzegorz Palamas, Homilia 37, cyt. za: Św. Grzegorz Palamas, Homilia na uroczystość Zaśnięcia Najświętszej Maryi Panny, przekł. ks. H. Paprocki, [w:] Teksty o Matce Bożej. Prawosławie, cz. 1, wybór, wstęp i oprac. ks. H. Paprocki, Niepokalanów 1991, s. 234.

${ }_{21}$ Wykopaliska archeologiczne wykazały, że w Konstantynopolu było około 200 świątyń na cześć Matki Bożej. O początkach kultu Matki Bożej w Konstantynopolu patrz: M. Fassler, The First Marian Feast in Constantinople and Jerusalem: Chant texts, Reading and Homiletic Literature, [w:] The Study of Medieval Chant. Paths and Bridges, East and West, Woodbridge 2000, s. 25-87.

22 Por. np. Ojcowie Wspólnej Wiary. Teksty o Matce Bożej (w. VIII-XI), przekł. i wstęp ks. W. Kania, Niepokalanów 1986.

23 Por. J. Klinger, Zarys prawosławnej mariologii, dz.cyt., s. 143.

24 A. Schmemann, Droga prawosławia w historii, dz.cyt., s. 207.
}

\section{Tytuły Matki Bożej}

Żaden inny święty w Kościele prawosławnym nie posiada tylu tytułów i określeń (jak też porównań, paraboli itd.) co Matka Boża. Nazywana jest przede wszystkim Bogurodzicą (gr. Theotokos, cs. Bogorodica), zawsze Dziewicą (gr. Aiparthenos, cs. Prisnodiewa) i (Prze-) Najświętszą (gr. Panagia, cs. Preswiataja). Za każdym razem podkreślane jest to podczas prawosławnych nabożeństw modlitewnym wezwaniem, które kierowane jest do „Najświętszej, przeczystej, błogosławionej, pełnej chwały Władczyni naszej Bogurodzicy i zawsze Dziewicy Marii”25.

Pierwszy z tych tytułów ${ }^{26}$ - Bogurodzica - został nadany Matce Bożej przez III Sobór Powszechny (431), po burzliwych dysputach i sporach św. Cyryla Aleksandryjskiego z Nestoriuszem ${ }^{27}$. „Ponieważ święta Dziewica urodziła cieleśnie Boga zjednoczonego hipostatycznie z ciałem, mówimy, że jest ona Bogarodzicą"28 - czytamy $\mathrm{w}$ dokumentach tego soboru, zaś $\mathrm{w}$ „Formule zjednoczenia" jego uczestnicy w skrócie wykładają tę naukę w następujący sposób: „Z racji zjednoczenia bez pomieszania (dwóch natur Chrystusa - przyp. J.Ch.) wierzymy, że święta Dziewica jest Bogarodzicą, ponieważ Słowo Boże się wcieliło, stało się człowiekiem i od chwili swego poczęcia zjednoczyło się ze świątynią, którą z Niej wzięło"29. Tym samym sobór ten na stałe umieścił mariologię w chrystologii. Dogmat o Bożym Macierzyństwie Bogurodzicy, ustanowiony w Efezie, jest jedynym, kluczowym dogmatem w Kościele prawosławnym dotyczącym Matki Bożej ${ }^{30}$. Tylko ten element nauczania Kościoła o Bogurodzicy (w przeciwieństwie do Kościoła rzymskokatolickiego ${ }^{31}$ ) został ujęty w ramy dogmatu. Przesłanki prowadzące do naro-

\footnotetext{
25 Formuła ta powtarzana jest bardzo często, np. Boska Liturgia świętego ojca naszego Jana Chryzostoma, Warszawa 2001, s. 37.

26 Ks. Georges Florowski trafnie zauważa, że „Theotokos jest czymś więcej niż nazwą czy honorowym tytułem. Jest to raczej doktrynalna definicja zawarta w jednym słowie", J. Florowskij, Matka Boża - zawsze Dziewica, przekł. J. Prokopiuk, [w:] Teksty o Matce Bożej. Prawosławie, cz. 1, dz.cyt., s. 174.

27 Nestoriusz doszedł do wniosku, że lepiej będzie określać Matkę Bożą mianem „Chrystorodzicy” (gr. Christotokos), por. Św. Cyryl Aleksandryjski, W obronie tytułu Bogarodzica, cyt. za: Św. Cyryl Aleksandryjski, Wykład prawdziwej wiary. W obronie tytułu Bogarodzica. Homilia Efezkie, tłum. ks. W. Kania, wstęp ks. E. Stanula, oprac. ks. E. Stanula i S. Kalinkowski, Warszawa 1980, s. 219. Termin „Chrystorodzica” nie wszedł do Tradycji Kościoła przede wszystkim właśnie z tego powodu, że został skompromitowany przez heretyka Nestoriusza.

28 Trzeci list Cyryla do Nestoriusza 24, cyt. za: Dokumenty Soborów Powszechnych, t. 1, dz.cyt., s. 151.

29 Formuła zjednoczenia, cyt. za: Dokumenty Soborów Powszechnych, t. 1, układ i oprac. ks. A. Baron, ks. H. Pietras SJ, Kraków 2007, s. 179.

30 Ks. Aleksy Kniazeff zauważa m.in., że dominacja w teologii prawosławnej dogmatu Bożego macierzyństwa sprawiła, że „zachodni temat mistycznych zaślubin nie został prawie rozwinięty przez liturgię bizantyjską", patrz: A. Kniazeff, Mariologia biblijna i liturgia bizantyjska, dz.cyt., s. 84, przyp. 30.

31 W XIX i XX w. Kościół ten ogłosił dwa nowe dogmaty dotyczące Matki Bożej: o Niepokalanym Poczęciu i Wniebowzięciu. Por. komentarz do tych dogmatów metropolity Kallistosa Ware: K. Ware, Kościót prawosławny, przekł. ks. W. Misijuk, Białystok 2002, s. 286-287 oraz metropolity Hilariona Ałfiejewa: Biskup Hilarion (Ałfiejew), Prawosławije, t. 1, Moskwa 2008, s. 725-726.
} 
dzin terminu „Bogurodzica” pojawiły się u zarania chrześcijaństwa, jeszcze wtedy, gdy Maria nosiła Dzieciątko w swoim łonie i została nazwana przez św. Elżbietę „,Matką mojego Pana"32 (Łk 1,43). Elżbieta nie nazywa jej tak po prostu, lecz pod wpływem Świętego Ducha (Łk 1,41). W czasach apostolskich wzmianka o tym, że Jednorodzony Syn Boży „urodził się z kobiety” (Ga 4,4) i „objawił się jako człowiek" $(1 \mathrm{Tm} 3,16)$ pojawily się w Listach ap. Pawła. Nauka Ojców Apostolskich (Ignacy Antiocheński) i św. Ojców II i III w. (Ireneusz z Lyonu, Dionizy Aleksandryjski, Piotr Aleksandryjski) prowadziła bezpośrednio do wypracowania terminu Bogurodzica (Theotokos), który po raz pierwszy użyty został zapewne przez Orygenesa ${ }^{33}$. Prawdopodobnie jako pierwszy w oficjalnym dokumencie kościelnym (liście okólnym do biskupów) terminu tego użył św. Aleksander z Aleksandrii (+ok. 326) ${ }^{34}$. W pismach św. Ojców końca IV w. (Atanazy Aleksandryjski, Cyryl Aleksandryjski, Grzegorz Teolog, Efrem Syryjczyk) pojęcie te było już powszechnie stosowane, nabierając charakteru kryterium prawidłowego wyznania wiary. „Słusznie i zgodnie z prawdą nazywany świętą Maryję Matką Boga. A ten tytuł zawiera w sobie całą tajemnicę Wcielenia" ${ }^{35}$ - pisał św. Jan z Damaszku. Uchwalenie dogmatu o Bogurodzicy przez sobór w Efezie przeniosło wcześniej już rozwijający się kult Matki Bożej z poziomu ludowej pobożności maryjnej na poziom teologiczny i duchowy. Sobór ten określił granice uwielbienia Bogurodzicy w Kościele, stawiając ją nieodłącznie z Jezusem Chrystusem, co zawdzięcza ona "macierzyństwu, otrzymanemu od Boga przez Ducha Świętego - macierzyństwu jednocześnie fizycznemu i duchowemu" ${ }^{\text {"36. }}$

W obronie drugiego tytułu - zawsze Dziewica - staną z kolei V Sobór Powszechny (553). Termin ten podkreśla dziewictwo Matki Bożej przed Narodzeniem Chrystusa, podczas Narodzenia Chrystusa i po Jego Narodzeniu, przy czym nie tylko w sensie czystości cielesnej, ale i duchowej ${ }^{37}$. Ojcowie tego soboru postanowili między innymi, że „Jeżeli ktoś nie wyznaje, że [...] Słowo zstąpiło z nieba, przyjęło ciało ze świętej i chwalebnej Bogarodzicy zawsze Dziewicy Maryi i z niej się narodziło - niech będzie przeklęty"38. Tytuł ten, w dziesiątym punkcie Dekretu wiary powtarzają również św. Ojcowie VII Soboru Powszechnego $(787)^{39}$. Termin ten jednak nigdy nie został wyjaśniony przez de-

\footnotetext{
32 Cytaty biblijne za tzw. Biblia Poznańską.

33 Pisze o tym Sokrates Scholastyk w swojej Historii Kościoła: Sokrates Scholastyk, Historia Kościoła VII, 32, przekł. S. Kazikowski, Warszawa 1986, s. 506

34 Por. D. Nellas, Nicolas Cabasylas: Theometer, Ateny 1968, s. 24 oraz A. Kniazeff, Matka Boża w Kościele prawosławnym, przekł. ks. H. Paprocki, Warszawa 1996, s. 57.

35 Św. Jan Damasceński, Wykład wiary prawdziwej 3, 12, 7, przekł. B. Wojkowski, Warszawa 1969, s. 156.

36 E. Behr-Sigel, Maryja, Matka Boga, przekł. M. Szczaniecka, [w:] Teksty o Matce Bożej. Prawosławie, cz. 2, dz.cyt., s. 213.

37 Prawosławna ikonografia obrazowa przedstawia to za pomocą trzech gwiazd umieszczanych na obu ramionach i na głowie Bogurodzicy.

38 Anatematyzmy przeciwko „Trzem rozdziałom” II, cyt. za: Dokumenty Soborów Powszechnych, t. 1, dz.cyt., s. 285, por. s. 281, 291 i 301.

39 Patrz: Dekret wiary 10, [w:] Dokumenty Soborów Powszechnych, t. 1, dz.cyt., s. 335.
}

finicje soborowe co, jak to trafnie ujął Paul Evdokimov, wynika zapewne z tego, że: „Wschód wykazuje wielką trzeźwość i wstydliwość, które zabraniają stawiać pytania o kwestie fizjologiczne, gdyż byłaby to ciekawość całkowicie nie na miejscu wobec misterium" ${ }^{\prime \prime}$.

Bł. Hieronim ze Strydonu (+419/420) potwierdza, że już Ojcowie Apostolscy Ignacy Antiocheński, Polikarp ze Smyrny, a także Ireneusz z Lyonu czy Justyn Męczennik, jak też wielu innych pisało na temat wiecznego dziewictwa Bogurodzicy ${ }^{41}$. Św. Jan z Damaszku podawał zaś: „A jak w poczęciu się swoim On (Syn Boży - przyp. J.Ch.) ocalił dziewictwo Tej, która Go poczęła, tak również w swoim narodzeniu zapewnił nienaruszalność” ${ }^{42}$, dodając: „Pozostała zatem i po urodzeniu Syna dziewicą ta Przeczysta Dziewica"43. Nauka o wiecznym dziewictwie Matki Bożej jest dla Kościoła prawosławnego wielką tajemnicą, w którą nie śmieli wnikać nawet św. św. Ojcowie.

Powszechne stosowane $\mathrm{w}$ prawosławiu trzeciego ze wspomnianych tytułów - określenia „Najświętsza” - nie jest związane z jakąś konkretna decyzją władz kościelnych ${ }^{44}$. Na tę świętość Bogurodzicy wskazuje jej całkowite uświęcenie, zarówno ciała, jak i duszy, przez Ducha Świętego. Klarownie ujął to Paul Evdokimov: „Jeżeli Duch Święty personifikuje świętość Boską, Dziewica personifikuje świętość ludzką" ${ }^{45}$. Podsumowując, skoro święci są ludźmi, w pewnym sensie wybranymi, to Bogurodzica, jako „Najświętsza” jest wybrana spośród wszystkich wybranych. W prawosławiu określenie (Prze-) Najświętszy/ -a bywa używane jedynie w trzech przypadkach: wobec Świętej Trójcy (cs. Preswjataja Troica, gr. Panahija Trias), Ducha Świętego (cs. Preswjatoj Duch, gr. Pneuma to Panhagion) i właśnie wobec Bogurodzicy (cs. Preswjataja Bogorodica, gr. Panhagia Theotokos).

Liczba określeń stosowanych wobec Bogurodzicy w prawosławiu jest ogromna. W wygłoszonej w Efezie homilii św. Cyryl Aleksandryjski (+386) nazywa ją np. „czcigodnym klejnotem całego świata, lampą, która nie gaśnie, koroną dziewiczości, berłem prawowiernej nauki, niezniszczalną świątynią, miejscem tego, którego miejscem ogarnąć się nie da"46. Prawdopodobnie najwięcej obrazowych i przemawiających do wyobraźni nazwań Matki Bożej zawiera jednak napisany przez św. Romana Melodosa w VI w. akatyst na cześć Zwiastowania Matki Bożej.

\footnotetext{
40 P. Evdokimov, Duch Święty i Matka Boża, przekł. ks. H. Paprocki, [w:] Teksty o Matce Bożej. Prawosławie, cz. 2, dz.cyt., s. 122.

41 Por. Św. Hieronim ze Strydonu, Przeciw Helwidiuszowi o wiecznym dziewictwie błogosławionej Marii, [w:] Teksty o Matce Bożej: Ojcowie Kościoła łacińscy, tłum. W. Eborowicz, W. Kania, Niepokalanów 1981, s. $80-100$.

${ }_{42}$ Św. Jan Damasceński, Wykład wiary prawdziwej 4, 14, 31, dz.cyt. s. 227. 43 Tamże.

44 Por. K. Ware, Kościót prawosławny, dz.cyt., s. 284-285 oraz K. Ware, Mary Theotokos in the Orthodox Tradition, "Marianum", LII, Roma 1990, s. 211-212.

45 P. Evdokimov, Ikona Matki Bożej Włodzimierskiej, przekł. M. Klinger, [w:] Teksty o Matce Bożej. Prawostawie, cz. 1, dz.cyt., s. 85.

46 Św. Cyryl Aleksandryjski, Homilia 4, cyt. za A. Bober, Światła Ekumeny. Antologia patrystyczna, Kraków 1995, s. 140.
} 


\section{Natura Matki Bożej}

Zgodnie z nauką Kościoła prawosławnego Bogurodzica uważana jest za „czcigodniejszą od cherubinów i nieporównywalnie sławniejszą od serafinów”. Na przeszkodzie temu nie stoi odziedziczona przez nią po przodkach pieczęć grzechu pierworodnego. Chociaż Maria posiada swój udział w grzechu pierworodnym, to została z niego oczyszczona przez Ducha Świętego w chwili poczęcia Zbawicie$\mathrm{la}^{47}$. Grzech pierworodny został więc w niej zmazany Duchem, zaś nosząc Syna Bożego w swoim łonie, jak i później, aż do końca swych ziemskich dni, pozostawała bezgrzesz$n a^{48}$. Jednak moc grzechu pierworodnego w niej wraz z jego następstwami - słabością i śmiertelnością ciała - pozostały.

Wśród chrześcijan cały czas obecna była wiara w osobistą bezgrzeszność Matki Chrystusa za życia oraz jej wyjątkową świętość. Podkreślali to zresztą św. Ojcowie IV w., porównując świętość i doskonałość Matki Bożej do bezgrzeszności i doskonałości Zbawiciela. Czynili to też późniejsi teologowie. Św. Grzegorz Palamas retorycznie zapytuje: „Jeżeli drzewo poznajemy po owocach i jeżeli dobre drzewo rodzi dobre owoce (Mt 7,17; Łk 6,44), to jakże Matka samej Dobroci i Rodzicielka Wiecznego Piękna nie powinna być doskonalsza od wszelkiego dobra, jakie istnieje w świecie przyrodzonym i nadprzyrodzonym"49. Jej wolność od osobistego grzechu, była nie tylko osobistym czynem Bogurodzicy, ale też czynem stopniowo oczyszczającej i wywyższającej za pomocą łaski aktywności poprzednich pokoleń, całego Kościoła Starego Testamentu. Zadaniem starotestamentowego Kościoła było bowiem przygotowanie ludzkości do godnego przyjęcia Ducha Świętego w osobie Bożej Rodzicielki, której doskonała świętość przewyższyła świętość świątyni i całą świętość Starego Testamentu ${ }^{50}$. Maria jest jego „ostatnim kwiatem, najbardziej jaśniejącym pięknem"51. Matka Boża reprezentuje najwyższą świętość osiągniętą przed Chrystusem, potomkami Adama, wyższą od świętości nowotestamentowej urzeczywistnianej w Kościele ${ }^{52}$.

Wcieleniem Syna Bożego Bogurodzica posłużyła „tajemnicy planu zbawienia” (Ef 3,9) rodzaju ludzkiego, zaś drugie zstąpienie Ducha Świętego - w dniu Pięćdziesiątnicy - związane było z jej osobistą świętością. „Oba te zstąpienia Ducha Świętego - funkcjonalne i osobiste - uzupełniają się wzajemnie" 53 - twierdzi wspomniany wyżej teolog. Pierwsze $\mathrm{z}$ nich miało charakter tajny, drugi czas publicz-

\footnotetext{
47 Por. N. Nissiotis, Maryja w teologii prawosławnej, dz.cyt., s. 100.

48 Por. S. Bułgakow, Bezgrzeszność Maryi, przekł. ks. H. Paprocki, [w:] Teksty o Matce Bożej. Prawosławie, cz. 1, dz.cyt., s. 92-96.

49 Św. Grzegorz Palamas, Homilia na święto Wprowadzenia Nieskalanej Pani naszej Bogurodzicy do Świętego Świętych, przekł. ks. H. Paprocki, [w:] Teksty o Matce Bożej. Prawosławie, cz. 2, dz.cyt., s. 233.

50 Por. A. Bloom, Wprowadzenie Matki Bożej do światyni, przekł. M. Klinger, [w:] Teksty o Matce Bożej. Prawosławie, cz. 2, dz.cyt., s. $280-281$.

51 A. Schmemann, Misterium miłości, dz.cyt., s. 204.

52 W. Łosski, Najświętsza, dz.cyt., s. 196.

53 W. Łosski, Wsieswjataja, [w:] Bogosłowije i Bogowidenije, zbiór artykułów, Moskwa 2000, s. 168
}

ny. Zstąpienie Ducha Świętego na Matkę Bożą i apostołów w dniu Pięćdziesiątnicy zakończyło ziemskie przebóstwienie ziemskiej natury Bogurodzicy, doprowadziło do odkupienia, stało się gwarancją jej zmartwychwstania po błogosławionym zaśnięciu ${ }^{54}$.

Maria stawiana jest tym samym za wzór życia duchowego. To ją Bóg wybrał spośród wszystkich niewiast na matkę swojego Syna, poprzez swojego Anioła nazwał Ją „łaski pełną” (Łk 1,28), a ustami Elżbiety „błogosławioną między niewiastami” (Łk 1,42). To ją, zgodnie z jej własnymi proroczymi słowami, będą błogosławić wszystkie narody i pokolenia (por. Łk 1,48). Cześć oddawana jej przez ludzi, to wyraz uznania dla jej wybrania przez Boga, jako Bożej pomocnicy w Jego odwiecznym planie zbawienia ludzkości.

Mówiąc o udziale Bogurodzicy w Bożym planie zbawienia, św. Ojcowie definiują dwa jego aspekty. Pierwszym jest jej wybranie przez Zamiar Przedwieczny, drugim zaś współuczestnictwo Marii w planie zbawienia ${ }^{55}$. Przy tym podkreślić należy, że świętość Matki Bożej wynika nie tylko z tego, że posiadała on jakiekolwiek przywileje, którymi obdarzona została $z$ racji swojego przyszłego Bogomacierzyństwa, lecz stanowi również rezultat jej wolności, wiary i życia. „Jej miłość do Boga osiągnęły w niej taką głębię i intensywność, że poczęcie Syna nastąpiło w Niej jako odpowiedź Boga na pogłębienie jej życia modlitwy, jej <przejrzystości> na energie Ducha Świętego" ${ }^{56}$ - pisze Paul Evdokimov. W innym miejscu używa on wobec Bogurodzicy pięknego określenia „dobrowolne poddanie się świętości” ${ }^{57}$, jako że bez jej zgody, bez współpracy jej wiary, Wcielenie Boże nie mogłoby zostać zrealizowane. Bardzo klarownie wyłożył tę myśl św. Mikołaja Kabasilas, pisząc: „...wcielenie Słowa było dziełem nie tylko Ojca i Jego mocy, i Ducha [...], lecz również dziełem woli i wiary Dziewicy" ${ }^{38}$. Matka Boża jest więc początkiem odnowienia, tą, która jeszcze przed Sądem Ostatecznym otrzymał pełnię chwały. W żadnym jednak razie nie stoi ona ponad zrodzonym z jej łona Chrystusem. „Czcijmy świętą Bogurodzicę, nie jako Boga, ale jako Matkę Boga ze względu na ciało"59 - nauczał św. Jan z Damaszku. To Jemu przynależy chwała, jej zaś cześć bardziej wyjątkowa niż innym świętym.

Reasumując powyższe, podkreślić należy, że w prawosławiu chwała oddawana Bogurodzicy ma wyraz chrystologiczny i jest ściśle związana z Drugą Osobą Trójcy Świętej. Posłuszeństwo Marii wobec woli Bożej stanowi najwyższy przykład synergii, współpracy człowieka z Bogiem, współpracy między Bożym zamysłem względem człowieka a ludzką wolnością ${ }^{60}$.

\footnotetext{
$54 \quad$ W. Saryczew, O kulcie Matki Bożej, dz.cyt. s. 165.

55 Por. Biskup Hilarion (Ałfiejew), Prawosławije, t. 1, dz.cyt., s. 721-722.

56 P. Evdokimov, Duch Święty i Matka Boża, dz.cyt., s. 125.

57 P. Evdokimov, Kult „Theotokos” - Matki Boga, przekł. M. Klinger, [w:] Teksty o Matce Bożej. Prawosławie, cz. 2. dz.cyt., s. 151.

58 M. Kabasilas, Homilia na uroczystość Zwiastowania Najświętszej Maryi Pannie, dz.cyt., s. 257.

59 Św. Jan Damasceński, III mowa obronna przeciw tym, którzy odrzucaja święte obrazy 41, przeł. M. Dylewska, „Vox Patrum” 29 (2009), t. 53-54, s. 650 , por. również rozdz. 28-33, s. 646-648

60 Por. J. Morris, ks., The Holy Tradition and the Veneration of Mary
} 


\section{Różne sfery kultu Matki Bożej}

Cześć oddawana w Kościele prawosławnym Matce Bożej posiada charakter dogmatyczny, ale też „współgra z podstawowymi tendencjami jego (wschodniego chrześcijaństwa - przyp. J.Ch.) duchowości” ${ }^{1}$. Kult ten „odciska swoje zbawienne piętno nie tylko na prawosławnej teologii, ale i na całym życiu modlitewnym i pobożności wiernych" - pisze metropolita Sawa Hrycuniak ${ }^{62}$. Dogmatyczne umocowanie czci oddawanej w prawosławiu Bogurodzicy znakomicie współgra z praktyczną realizacją tego kultu, która to realizacja - jak i kult innych świętych - znajduje swój wyraz w wielu sferach życia Kościoła.

Bogurodzica jest nade wszystko wszechobecna w całym kościelnym roku liturgicznym, w liturgicznej i modlitewnej sferze życia Kościoła. Kierowana pod jej adresem modlitwa Kościoła o pomoc i orędownictwo u jej Syna zajmuje w prawosławnym nabożeństwie miejsce bardziej znaczące niż modlitwa do pozostałych świętych. Świadczy o tym częstotliwość oraz różnorodność wspominania jej w nabożeństwach, jak też ogromna liczba modlitw do niej. Prowadzi to do konkluzji, że Matka Boża jest nieustannie obecna w życiu liturgicznym prawosławia oraz we wszystkich najważniejszych momentach funkcjonowania Kościoła oraz życia w Chrystusie każdego chrześcijanina ${ }^{63}$. „Liturgia bizantyjska (czy szerzej prawosławna - przyp. J.Ch.) jest najbardziej maryjną ze wszystkich liturgii”"64 - pisał ks. Aleksy Kniazeff, z czym nie sposób się nie zgodzić.

Kościół prawosławny podkreśla szczególną moc modlitwy do Matki Bożej. Prosząc o jej pomoc i wstawiennictwo przed Synem, kieruje pod jej adresem wezwanie „zbaw nas”, a nie tylko „módl się za nas do Boga”, jak czyni to w modlitwach do świętych ${ }^{65}$. Wezwanie to wskazuje na udział Bogurodzicy w dziele zbawienie i odkupienia. Nie oznacza ono, że Bogurodzica posiada możliwość udzielania zbawienia, lecz „oznacza jedynie pokorną prośbę: $<$ Spraw przez Twe modlitwy do naszego Zbawiciela, abyśmy stali się w naszym życiu chrześcijańskim prawdziwymi dziećmi Bożymi>"66.

W prawosławiu Bogurodzica nie jest jedynie Pomocnicą w zbawieniu, tak jak pozostali święci i aniołowie,

and other Saints in the Orthodox Church, "The Word" 2007, nr 7, s. 3 oraz K. Ware, Kościół prawosławny, przekł. ks. W. Misijuk, Białystok 2002, s. 285. ${ }^{61}$ T. Špidlík, Molitwa sogłasno predaniju Wostocznoj Cerkwi, www. bogoslov.ru/text/print/2485575/html [dostęp 24.10.2013].

${ }_{2}$ Cyt. za: J. Charkiewicz, Toba raduje się całe stworzenie. Ikony Bogarodzicy w Prawosławiu, Warszawa 2009, s. 5.

${ }_{63}$ Miejsce Matki Bożej w liturgii prawosławnej niejednokrotnie było przedmiotem dociekań uczonych, np.: S. Salaville, Marie dans la liturgie byzantine ou gréco-slave, [w:] Maria 1, Paryż 1949, J. Ledit, Marie dans la liturgie byzantine, Paryż 1976; Mnich Kościoła Wschodniego, L’an de grâce du Seigneur, I i II, Bejrut 1972-1973; A. Kniazeff, The Great Sign of the Heavenly Kingdom, «St. Vladimir's Theological Quarterly» 1969, nr 13, z. 1 i 2 ; A. Kniazeff, Obecność Matki Bożej w liturgii, dz.cyt., s. 51-85.

${ }^{64}$ A. Kniazeff, Obecność Matki Bożej w liturgii, dz.cyt., s. 51.

65 Por. I. Aksionow, ks., Bogosłowskije osnowanija poczitanija Preswjatoj Bogorodicy, www.bogoslov.ru/text/print/2227674.html [dostęp 24.10.2013].

${ }^{66}$ A. Kniazeff, Miejsce Maryi w pobożności prawosławnej, przekł. M. Klinger, [w:] Teksty o Matce Bożej. Prawosławie, cz. 1, dz.cyt., s. 65-66. lecz wzywana jest jako ta, która dokonała zbawienia. Wiarę w szczególną moc próśb kierowanych do Matki Bożej usprawiedliwia nie tylko fakt Bożego macierzyństwa, lecz również wiedza o tym, że stała się ona Bogurodzicą dlatego, iż podobna jest do swojego Syna pod względem miłości, miłosierdzia i łaskawej pomocy. Nie może być zatem modlitwy bardziej skutecznej od tej skierowanej do Bogurodzicy $^{67}$.

W Kościele prawosławnym na cześć Matki Bożej ustanowiono wiele świąt. Spośród tzw. wielkich świąt z liczby dwunastu, cztery zostały ustanowione na pamiątkę najważniejszych wydarzeń z jej życia: Narodzenie Bogurodzicy, Wprowadzenie Bogurodzicy do Świątyni, Zwiastowanie Bogurodzicy oraz Zaśnięcie Bogurodzicy ${ }^{68}$. Jednak i te święta w istocie mają charakter chrystologiczny, ściśle maryjny posiadają inne celebracje: na cześć rodziców Bogurodzicy - świętych Joachima i Anny, poczęcie Bogurodzicy, Zaśnięcie Matki Bogurodzicy - św. Anny, Synaksa (Soboru) Bogurodzicy ${ }^{69}$, Opieka Matki Bożej, złożenie czcigodnej szaty Bogurodzicy w Blachernach, złożenie pasa Bogurodzicy w Chalkopratei, Pochwała Bogurodzicy (Sobota Akatystu), odnowienie świątyni Bogurodzicy „Źródło Życia” w Konstantynopolu (obchodzone w piątek Tygodnia Paschalnego). Do świąt maryjnych w przeważającym stopniu o charakterze lokalnym należą te, podczas których czczona jest pamięć jej cudownych ikon. Ich liczba przewyższa obecnie $400^{70}$.

Matka Boża nie przestaje modlić się za chrześcijan i przychodzić im z pomocą w odpowiedzi na modlitewne wezwania. Dlatego też Jej kult rozwija się w dalszym ciągu, poprzez ustanawianie nowych świąt na cześć jej cudownych ikon oraz tworzenie kolejnych hymnów związanych z tymi świętami i ikonami.

Reasumując należy przywołać słowa ks. Aleksego Kniazeffa: „przez modlitwy i wstawiennictwo jest Ona (Bogurodzica - przyp. J.Ch.) bardziej niż święci obecna w życiu ziemskiego Kościoła"71, co znajduje swój wyraz m.in. w niemal niezliczonej liczbie świąt na jej cześć (w szczególności czczonych, cudownych ikon), co z kolei jest wynikiem różnorodnych łask, których ze strony Matki Bożej doświadczają wierni zanoszący do niej swoje modlitwy.

W przeciwieństwie do niektórych świętych, w przypadku Bogurodzicy nie można mówić o kulcie jej relikwii. Wspomniano już że, zgodnie z nauką Kościoła prawosławnego, nie zmarła ona lecz zasnęła i została wzięta ciałem

\footnotetext{
${ }_{67}$ Por. J. Charkiewicz, Toba raduje się całe stworzenie..., dz.cyt., s. 9 oraz W. Saryczew, O kulcie Matki Bożej, dz.cyt. s. 170.

68 Początkowo (a przez niektórych autorów również obecnie) Spotkanie Pańskie niekiedy traktowano jako święto maryjne, nazywając je nawet Spotkaniem Bogurodzicy, por. J. Charkiewicz, Wielkie święta prawosławne. Zarys historii i ikonografii, Warszawa 2013, s. 72.

69 Ks. Jerzy Klinger czy ks. Aleksander Schmemann zasadnie przypuszczają, że święto to, jako bezpośrednio związane z obchodami Narodzenia Chrystusa, mogło być chronologicznie pierwszym świętem maryjnym; patrz: J. Klinger, Zarys prawosławnej mariologii, dz.cyt., s. 144 oraz A. Schmemann, Maryja w liturgii wschodniej, dz.cyt., s. 88.

70 Tomáš Špidlík podaje nawet, że w kalendarzu w przedrewolucyjnej Rosji znajdowało się ponad tysiąc świąt ku czci różnych ikon Matki Bożej, T. Špidlík, Molitwa sogłasno predaniju Wostocznoj Cerkwi, dz.cyt.

71 A. Kniazeff, Obecność Matki Bożej w liturgii, dz.cyt., s. 55-56.
} 
do nieba. Jej relikwie nie mogą więc służyć za podwaliny ołtarzy nowych świątyń. Wyjątek stanowią relikwie wtórne, a mianowicie jej szata (cs. riza) i pas (cs. pojas), na cześć których ustanowiono specjalne święta.

Niezwykle rozwinięta jest natomiast ikonografia przedstawień Bogurodzicy,jej korzenie tkwią w pierwszych wiekach istnienia Kościoła. Najstarszy zachowany wizerunek (fresk) przedstawiające Matkę Bożą (z obnażonym Dzieciątkiem na rękach) znajduje się w rzymskich katakumbach św. Pryscylli i pochodzi z końca II - początku III wieku ${ }^{72}$. Rozwój ikonografii maryjnej nastąpił od VI w., okresowo został zahamowany przez herezję ikonoklazmu. Największy rozkwit datujemy natomiast na XIII-XVI wiek. W prawosławnej ikonografii wizerunek Bogurodzicy zajmuje miejsce po wyobrażeniach Jezusa Chrystusa i tworzy z nimi harmonijną całość. Ikonografia Matki Bożej liczbą typów i wariantów przewyższa nawet liczbę ikon Zbawiciela, nie mówiąc o liczbie wariantów ikon najbardziej popularnych świętych. Poza nielicznymi wyjątkami przedstawiają one Bogurodzicę w Dzieciątkiem na rękach lub na jej łonie. Matka Boża występuje sama jedynie w tych przedstawieniach historycznych scen, gdzie Chrystusa jeszcze się nie narodził i nie jest obecny w sposób widzialny. Każda z cudownych ikon Bogurodzicy posiada swój dzień wysławiania i kult liturgiczny. Ikony Matki Bożej zajmują też szczególnie ważne miejsce w ikonostasach prawosławnych świątyń.

Opis życia Bogurodzicy jest nie mniej niż żywoty świętych przedmiotem zainteresowania Kościoła, tym bardziej, że mieści on wzorzec świętości. Opis życia Matki Bożej bazuje na Piśmie Świętym, Tradycji Kościoła i pomocniczo na pismach apokryficznych z „Protoewangelią Jakuba” (koniec II w.) na czele. Żywoty Matki Bożej w prawosławiu można podzielić na trzy zasadnicze grupy. Pierwsza z nich to typowy opis jej życia, zaczynając od Narodzenia do Zaśnięcia. Druga to kompilacje, na które składają się opisy życia Matki Bożej połączone z opisami dziejów jej cudownych ikon oraz cudów z nimi związanych. Grupa trzecia, współcześnie największa, to prace przedstawiające cuda i losy poszczególnych cudownych ikon Bogurodzicy z pominięciem jej żywota.

Podobnie jak święci, a nawet częściej Bogurodzica jest patronką nowo budowanych świątyń, a szczególnie monasterów. Zawsze jednak związane jest to nie tyle z samym jej imieniem Maria, co z określonym świętem na jej cześć: Narodzenie, Wprowadzenie do Świątyni, Zwiastowanie, Zaśnięcie, Opieka Matki Bożej czy też jej cudownymi ikonami (np. Kazańska, Włodzimierska itd.). Wezwanie maryjne nadawane były w szczególności świątyniom znajdującym się w miejscach ziemskiego życia Bogurodzicy: Nazaret, Betlejem, Jerozolima, a od IV w. w stolicy Cesarstwa Konstantynopolu.

Tradycja słowiańska, w przeciwieństwie do greckiej, nie zna nadawania dzieciom na chrzcie imienia Boguro-

\footnotetext{
72 N. W. Kwliwidze, Ikonografija Bogorodicy, [w:] Prawosławnaja Encikłopiedija, t. 5, Moskwa 2002, s. 502; niektórzy odnoszą to wyobrażenie nawet do końca I wieku, patrz: P. Allard, Rome souterraine, Paryż 1874, s. 281.
}

dzicy, tj. Marii, a zatem obierania Matki Bożej za patronkę nowo chrzczonej osoby. Imię „Maria” często nadawane jest na chrzcie, lecz nie na cześć Bogurodzicy, lecz w odniesieniu do jednej z wielu świętych o tym samym imieniu. Uzasadnienie takiej tradycji może stanowić przeświadczenie, że Matka Boża może być uważana za niebiańską patronkę wszystkich ludzi bez względu na to, którego świętego imię noszą.

\section{Podsumowanie}

Teologiczne podstawy kultu Matki Bożej w Kościele prawosławnym oraz granice tej czci można sprowadzić do kilku zasadniczych elementów:

1. Kult Bogurodzicy od początku istnienia Kościoła, zakorzeniony jest w Piśmie Świętym oraz Tradycji, a w ekonomii zbawienia bazuje na relacjach z jej Synem, Jezusem Chrystusem.

2. Chociaż w Bogurodzicy nastąpiło uwieńczenie stworzenia i uważana jest ona za stojącą ponad światem anielskim i przewyższającą wszystkich innych świętych, to cześć jej oddawana zdecydowanie różni się od chwały należnej wyłączenie Trójjedynemu Bogu.

3. Kult Bogarodzicy jest powiązany $\mathrm{z}$ chwałą oddawaną Jezusowi Chrystusowi, a wynika nie tylko z jej osobistych cnót, a przede wszystkim z wyjątkowej roli w ekonomii zbawienia. Kult ten jest nie tyle przedmiotem, co owocem wiary Kościoła w jej wyjątkowe miejsce w tejże ekonomii. Cześć oddawana Bogurodzicy (cs. poczitanije, gr. duleia, hyperduleia, proskynesis) nie służy umniejszaniu chwały należnej Chrystusowi (cs. proslawlenije, gr. latreia), będącemu źródłem wszelkiej świętości, w tym Swojej Matki, lecz potęgowaniu tej chwały. Tym samym dzięki Swojej Matce, Jezus Chrystus staje się wiernym bliższy i bardziej osiągalny.

4. W Kościele prawosławnym Matka Boża jest zawsze wychwalana i przedstawiana z Chrystusem pośród innych świętych, jako wyraz wspólnoty celebrującej i modlitewnej, a oddawanie czci Bogurodzicy związane jest ze stawianiem jej za najwyższy z możliwych wzór do naśladowania dla ludzi wierzących.

5. Bogurodzica stoi na czele świętość Kościoła, a jej świętość jest nieporównywalna $\mathrm{z}$ żadną inną ludzką świętością. „Ona jest chwała przebywających na ziemi i radością będących w niebie, źródłem i korzeniem niewypowiedzianych dóbr, Ona jest szczytem i doskonałością wszystkiego, co święte" ${ }^{\text {"73 }}$, błogosławioną nie tylko między niewiastami (por. Łk 1,42), ale też między wszystkimi ludźmi i wszystkimi świętymi. Ludzie wierzący nie mają większej od niej orędowniczki przed Bogiem. Cały zespół elementów, z których składa się tak głęboki kult Bogurodzicy w Kościele prawosławnym świadczy o tym, że stanowi on jedną z głównych cech prawosławia.

\footnotetext{
73 Św. Grzegorz Palamas, Homilia 37, dz.cyt., s. 234.
} 


\section{Bibliografia}

I. Aksionow, ks., Bogosłowskije osnowanija poczitanija Preswjatoj Bogorodicy, www.bogoslov.ru/text/print/2227674.html [dostęp 24.10.2013].

P. Allard, Rome souterraine, Paryż 1874.

A. Bloom, Wprowadzenie Matki Bożej do światyni, przekł. M. Klinger, [w:] Teksty o Matce Bożej. Prawosławie, cz. 2, wybór, wstęp i oprac. ks. H. Paprocki, Niepokalanów 1991.

A. Bober, Światła Ekumeny. Antologia patrystyczna, Kraków 1995.

Boska Liturgia świętego ojca naszego Jana Chryzostoma, Warszawa 2001.

E. Behr-Sigel, Maryja, Matka Boga, przekł. M. Szczaniecka, [w:] Teksty o Matce Bożej. Prawosławie, cz. 2, wybór, wstęp i oprac. ks. H. Paprocki, Niepokalanów 1991.

S. Bułgakow, Bezgrzeszność Maryi, przekł. ks. H. Paprocki, [w:] Teksty o Matce Bożej. Prawosławie, cz. 1, wybór, wstęp i oprac. ks. H. Paprocki, Niepokalanów 1991.

S. Bułgakow, Mariologia czwartej Ewangelii, przekł. ks. H. Paprocki, [w:] Teksty o Matce Bożej. Prawosławie, cz. 1, wybór, wstęp i oprac. ks. H. Paprocki, Niepokalanów 1991.

S. Bułgakow, Prawosławie. Zarys nauki Kościoła prawosławnego, przekł. ks. H. Paprocki, Białystok - Warszawa 1992.

J. Charkiewicz, Tobq raduje się całe stworzenie. Ikony Bogarodzicy w Prawosławiu, Warszawa 2009.

J. Charkiewicz, Wielkie święta prawosławne. Zarys historii i ikonografii, Warszawa 2013.

Św. Cyryl Aleksandryjski, Wykład prawdziwej wiary. W obronie tytułu Bogarodzica. Homilia Efezkie, przekł. ks. W. Kania, wstęp ks. E. Stanula, oprac. ks. E. Stanula i S. Kalinkowski, Warszawa 1980.

Dokumenty Soborów Powszechnych, t. 1, układ i oprac. ks. A. Baron, ks. H. Pietras SJ, Kraków 2007.

P. Evdokimov, Duch Święty i Matka Boża, przekł. ks. H. Paprocki, [w:] Teksty o Matce Bożej. Prawosławie, cz. 2, wybór, wstęp i oprac. ks. H. Paprocki, Niepokalanów 1991.

P. Evdokimov, Ikona Matki Bożej Włodzimierskiej, przekł. M. Klinger, [w:] Teksty o Matce Bożej. Prawosławie, cz. 1, wybór, wstęp i oprac. ks. H. Paprocki, Niepokalanów 1991.

P. Evdokimov, Kult „Theotokos” - Matki Boga, przekł. M. Klinger, [w:] Teksty o Matce Bożej. Prawosławie, cz. II, wybór, wstęp i oprac. ks. H. Paprocki, Niepokalanów 1991.

M. Fassler, The First Marian Feast in Constantinople and Jerusalem: Chant texts, Reading and Homiletic Literature, [w:] The Study of Medieval Chant. Paths and Bridges, East and West, Woodbridge 2000.

P. Florenski, Ziemska droga Matki Bożej, przekł. ks. H. Paprocki, [w:] Teksty o Matce Bożej. Prawosławie, cz. 1, wybór, wstęp i oprac. ks. H. Paprocki, Niepokalanów 1991.

J. Florowskij, Matka Boża - zawsze Dziewica, przekł. J. Prokopiuk, [w:] Teksty o Matce Bożej. Prawosławie, cz. 1, wybór, wstęp i oprac. ks. H. Paprocki, Niepokalanów 1991.

Św. Grzegorz Palamas, Homilia na uroczystość Zaśnięcia Najświętszej Maryi Panny, przekł. ks. H. Paprocki, [w:] Teksty o Matce Bożej. Prawosławie, cz. 1, wybór, wstęp i oprac. ks. H. Paprocki, Niepokalanów 1991.

Św. Grzegorz Palamas, Homilia na święto Wprowadzenia Nieska- lanej Pani naszej Bogurodzicy do Świętego Świętych, przekł. ks. H. Paprocki, [w:] Teksty o Matce Bożej. Prawosławie, cz. 2, wybór, wstęp i oprac. ks. H. Paprocki, Niepokalanów 1991.

Św. Hieronim ze Strydonu, Przeciw Helwidiuszowi o wiecznym dziewictwie błogosławionej Marii, [w:] Teksty o Matce Bożej: Ojcowie Kościoła łacińscy, tłum. W. Eborowicz, W. Kania, Niepokalanów 1981.

Biskup Hilarion (Ałfiejew), Prawosławije, t. 1, Moskwa 2008.

Św. Jan Damasceński, Wykład wiary prawdziwej, przekł. B. Wojkowski, Warszawa 1969.

Św. Jan Damasceński, III mowa obronna przeciw tym, którzy odrzucaja święte obrazy, przeł. M. Dylewska, „Vox Patrum” 29 (2009), t. 53-54.

Św. Justyn Popović, Sobranije tworenij prepodobnogo Iustina (Popovića). Pnewmatologija. Eschatologia, t. 4, Moskwa 2007.

M. Kabasilas, Homilia na uroczystość Zaśnięcia Najświętszej Marii Panny, [w:] Teksty o Matce Bożej. Prawosławie, cz. 1, wybór, wstęp i oprac. ks. H. Paprocki, Niepokalanów 1991.

M. Kabasilas, Homilia na uroczystość Zwiastowania Najświętszej Maryi Pannie, [w:] Teksty o Matce Bożej. Prawosławie, cz. 1, wybór, wstęp i oprac. ks. H. Paprocki, Niepokalanów 1991.

J. Klinger, Zarys prawosławnej mariologii, [w:] Teksty o Matce Bożej. Prawosławie, cz. 1, wybór, wstęp i oprac. ks. H. Paprocki, Niepokalanów 1991.

A. Kniazeff, Mariologia biblijna i liturgia bizantyjska, przekł. ks. H. Paprocki, [w:] Teksty o Matce Bożej. Prawosławie, cz. 2, wybór, wstęp i oprac. ks. H. Paprocki, Niepokalanów 1991.

A. Kniazeff, Matka Boża w Kościele prawosławnym, przekł. ks. H. Paprocki, Warszawa 1996.

A. Kniazeff, Miejsce Maryi w pobożności prawosławnej, przekł. M. Klinger, [w:] Teksty o Matce Bożej. Prawosławie, cz. 1, wybór, wstęp i oprac. ks. H. Paprocki, Niepokalanów 1991.

A. Kniazeff, Obecność Matki Bożej w liturgii, przekł. ks. H. Paprocki, [w:] Teksty o Matce Bożej. Prawosławie, cz. 2 wybór, wstęp i oprac. ks. H. Paprocki, Niepokalanów 1991.

A. Kniazeff, The Great Sign of the Heavenly Kingdom, «St. Vladimir's Theological Quarterly»1969, nr 13, z. 1 i 2.

N.W. Kwliwidze, Ikonografija Bogorodicy, [w:] Prawosławnaja Encikłopiedija, t. 5, Moskwa 2002.

J. Ledit, Marie dans la liturgie byzantine, Paryż 1976.

W. Łosski, Najświętsza, przekł. ks. H. Paprocki, [w:] Teksty o Matce Bożej. Prawosławie, cz. 1, wybór, wstęp i oprac. ks. H. Paprocki, Niepokalanów 1991.

W. Łosski, Wsieswjataja, [w:] Bogosłowije i Bogowidenije, zbiór artykułów, Moskwa 2000.

Mnich Kościoła Wschodniego, Lan de grâce du Seigneur, I i II, Bejrut 1972-1973.

J. Morris, ks., The Holy Tradition and the Veneration of Mary and other Saints in the Orthodox Church, "The Word" 2007, nr 7.

D. Nellas, Nicolas Cabasylas: Theometer, Ateny 1968.

N. Nissiotis, Maryja w teologii prawosławnej, przekł. B. GórskaKozłowska, [w:] Teksty o Matce Bożej. Prawosławie, cz. 2, wybór, wstęp i oprac. ks. H. Paprocki, Niepokalanów 1991.

Ojcowie Wspólnej Wiary. Teksty o Matce Bożej (w. VIII-XI), przekł. i wstęp ks. W. Kania, Niepokalanów 1986. 
Przedziwny Bóg $w$ świętych swoich. O świętości i o świętych z o. Szczepanem T. Kraśkiewiczem OCD rozmawia Kajetan Rajski, Kraków 2011.

S. Salaville, Marie dans la liturgie byzantine ou gréco-slave, [w:] Maria 1, Paryż 1949.

W. Saryczew, O kulcie Matki Bożej, przekł. Z. Kozłowska, [w:] Teksty o Matce Bożej. Prawosławie, cz. 2, wybór, wstęp i oprac. ks. H. Paprocki, Niepokalanów 1991.

A. Schmemann, Droga prawosławia $w$ historii, przekł. ks. H. Paprocki, Białystok 2001.
A. Schmemann, Maryja w liturgii wschodniej, przekł. J. Prokopiuk, [w:] Teksty o Matce Bożej. Prawosławie, cz. 2, wybór, wstęp i oprac. ks. H. Paprocki, Niepokalanów 1991.

Sokrates Scholastyk, Historia Kościoła, przekł. S. Kazikowski, Warszawa 1986.

T. Špidlík, Molitwa sogłasno predaniju Wostocznoj Cerkwi, www. bogoslov.ru/text/print/2485575/html [dostęp 24.10.2013].

K. Ware, Kościót prawosławny, przekł. ks. W. Misijuk, Białystok 2002.

K. Ware, Mary Theotokos in the Orthodox Tradition, "Marianum", LII, Roma 1990.

Rozmiar artykułu: 1 arkusz wydawniczy 